\title{
Diet of the sea anemone Anthopleura nigrescens: composition and variation between daytime and nighttime high tides
}

\author{
Andrés J Quesada ${ }^{*}$, Fabián H Acuña ${ }^{2}$ and Jorge Cortés ${ }^{1}$
}

\begin{abstract}
Background: The diverse feeding habits of sea anemones have led them to be classified as opportunistic polyphagous predators. However, most studies have focused on the diet of temperate sea anemones, and little is known about the trophic ecology of tropical species and their role in tropical ecosystems. We studied the diet of the intertidal sea anemone Anthopleura nigrescens by examining the gut contents of specimens collected at two sites on Costa Rica's Pacific coast, testing for differences in prey items captured between daytime and nighttime high tides.
\end{abstract}

Results: We found 25 prey items including: mollusks, crustaceans, annelids, insects and eggs. Juvenile bivalves, barnacle cyprids, and copepods were the main prey items. The anemones at Playa Dominical captured significantly more juvenile bivalves during nighttime high tides, and those at Mata de Limón captured more cyprids during daytime high tides.

Conclusions: This study shows that A. nigrescens is an opportunistic polyphagous predator, like most of its temperate counterparts.

Keywords: Anthopleura nigrescens; Costa Rica; Diet; Pacific; Prey; Sea anemone; Trophic ecology

\section{Background}

Anthopleura nigrescens (Verrill 1928) is a common, azooxanthellate sea anemone in the rocky intertidal habitats of Costa Rica's Pacific coast. It is most abundant in the lower intertidal zone, but can occur in the middle and upper zones, usually in crevices or pools (Acuña et al. 2012). This species forms large aggregations of individuals that during low tide retract their tentacles to reduce desiccation. Aggregating behavior and adhesive verrucae that attach gravel to the column also diminish desiccation (Hart and Crowe 1977; Bingham et al. 2011), and presumably allow $A$. nigrescens to colonize hot, tropical intertidal zones. This species was redescribed in detail using specimens from Hawaii (Dunn 1974) and was only recently recorded for Costa Rica, indicating that it is distributed across the Indo-Pacific (Acuña et al.

\footnotetext{
* Correspondence: andresjquesada@gmail.com

'Centro de Investigación en Ciencias del Mar y Limnología (CIMAR), Ciudad de la Investigación, Universidad de Costa Rica, San Pedro, San José 11501-2060, Costa Rica

Full list of author information is available at the end of the article
}

2012). Its abundance and ease of identification and collection in the field make it an ideal species for trophic ecology studies.

The diet of sea anemones is an interesting aspect of their ecology and diet studies provide insight into their role in trophic webs. Several authors have characterized sea anemones as opportunistic polyphagous predators that feed on the available prey, usually benthic organisms, in their surrounding environment (Chintiroglou and Koukouras 1991; Acuña and Zamponi 1996; Acuña et al. 2001). For example, Acuña and Zamponi (1996) studied the diet of three temperate species and found that their main prey was the bivalve Brachidontes rodriguezi, which was also the most abundant organism in the sampled areas. Other studies on temperate anemones have found that diet changes seasonally (Chintiroglou and Koukouras 1992; Acuña and Zamponi 1995). For example, Acuña et al. (2001) observed that Anthothoe chilensis feeds mainly on gammarid crustaceans that are abundant during the summer, but feeds on pycnogonids, cirratulid polychaetes and caprellid crustaceans during 
the other seasons. Studies have also shown that the diet of one species may vary between different locations (Kruger and Griffiths 1998; Tsurpalo and Kostina 2003; Davenport et al. 2011), or even between different depths at a same site (Chintiroglou and Koukouras 1992). These findings have led authors to suggest that the diet of sea anemones reflects the prey availability in the communities they inhabit (Chintiroglou and Koukouras 1992; Tsurpalo and Kostina 2003).

Although the diets of many temperate sea anemone species have been well documented, there is a considerable gap in our knowledge of the trophic ecology of tropical species. In this study we describe the diet of $A$. nigrescens and compare the composition of the diet between locations. We also tested the hypothesis that the diet would change between daytime and nighttime high tides, presumably due to temporal differences in prey availability.

\section{Methods}

\section{Collection and sampling}

A total of 158 specimens were collected from two sites on Costa Rica's Pacific coast: a rocky promontory that extends towards the sandy beach in Playa Dominical $\left(9^{\circ} 15^{\prime}\right.$ $\left.00^{\prime \prime} \mathrm{N}, 83^{\circ} 51^{\prime} 36^{\prime \prime} \mathrm{W}\right)$ and an artificial breakwater in Mata de Limón $\left(9^{\circ} 55^{\prime} 15^{\prime \prime} \mathrm{N}, 84^{\circ} 42^{\prime} 53^{\prime \prime} \mathrm{W}\right)$. These sites were selected because they are easily accessible and have large aggregations of $A$. nigrescens that are exposed during low tide.

On 3 and 4 April 2012, 88 specimens were collected from Playa Dominical, 44 specimens after a daytime high tide near noon and another 44 specimens after a nighttime high tide near midnight. Then, on 22 and 23 April 2013, 70 specimens were collected from Mata de Limón, 35 specimens again after a noon high tide and 35 specimens after a midnight high tide. In both cases, the collection dates were within 4 days of spring tides (and full moons) because the low tides allowed for a longer collecting period. The sea anemones were collected as soon as possible after they were exposed by the falling tide to reduce the digestion time and allow the extraction of fresh prey from the sea anemone coelenterons. Specimens were placed in seawater and were narcotized with small additions of a $7.5 \%$ magnesium chloride solution (Moore 1989), which reduced regurgitation of the food bolus upon addition of the preservative. Finally, specimens were fixed by adding concentrated formalin to reach a $6 \%$ formalin in seawater solution.

In the laboratory the specimens were washed with tap water to remove the formalin and placed in $70 \%$ ethanol until processing, which was carried out within three months of the collection date. Before dissection, attached gravel was removed with forceps from each specimen and detritus was washed off. Specimens were dissected on a petri dish by carefully cutting them longitudinally and removing the food bolus and large prey items with forceps. Then, a scalpel was used to scrape the mesenteric filaments from the mesenteries and the coelenteron was flushed several times. The petri dish was examined under a stereoscope and prey items were identified to the lowest possible taxonomic level and counted. Whether the items were undigested, partially digested, or completely digested was also noted. For example, empty crustacean exoskeletons were noted as completely digested, whereas exoskeletons with some tissue were noted as partially digested. This distinction was also applied to mollusk shells.

\section{Data analyses}

The methods described by Deniel (1975) with the modified terminology by Acuña and Zamponi (1995) were used to calculate the following parameters: percentage of empty gastric cavities or vacuity index (V), frequency index of each prey item (f), and percentage of each prey item $(\mathrm{P})$.

To obtain the composition of the diet of $A$. nigrescens populations at Playa Dominical and Mata de Limón, the data from all individuals collected after both high tides at each site were combined. All prey items were taken into account, including completely digested, partially digested and undigested items. Preliminary analyses showed that there were no statistically significant differences in prey item composition between sites.

To compare between the composition of prey items captured during daytime and nighttime high tides, the same methodology as above was applied, but only partially digested and undigested prey items were included in the analyses. Sea anemone coelenterons may contain a mix of freshly captured and old prey items (Davenport et al. 2011). Thus, fully digested prey items were excluded to ensure that all prey items included in the analyses had been captured exclusively during the previous high tide. We assumed that old prey items were completely digested during the previous tidal cycle (approximately 12 hours). Sea anemone digestion rates depend on the type of prey, the size of the prey items and the anemone species. However, the average digestion time of the temperate species Anthopleura elegantissima is 8 to 9 hours (Hiebert and Bingham 2012) and previous studies show that digestion rates are faster at higher temperatures and with exposure to sunlight (Kruger and Griffiths 1997; Rossi et al. 2004; Purcell 2009; Hiebert and Bingham 2012).

Data were analyzed with the statistical software PAST v.2.15 (Hammer et al. 2001). A one-way Analysis of Similarity (ANOSIM) test was used to find differences in the composition of prey items captured during daytime and nighttime high tides. To determine which prey items contribute most to the differences between the tides, a Similarity Percentage (SIMPER) test was used. The 
abundances of all prey items were square root transformed prior to analyses, to prevent the most abundant prey from dominating the analyses.

\section{Results}

A total of 158 sea anemone coelenterons were analyzed. These contained 25 different prey items, distributed in five groups: mollusks, crustaceans, insects, annelids, and eggs (Figures 1 and 2). Prey items were found in all coelenterons examined, resulting in a vacuity index of $0 \%$. However, when only semidigested or undigested prey items were included, the vacuity index was 3\%. Most prey items found were highly digested. Mollusk shells were usually found whole, occasionally with mesenteric filaments still inside the shell, indicating that digestion was ongoing at the time of fixation. Brachidontes sp. bivalves were always found with their shells open, on rare occasions with some remaining tissue. Unidentified juvenile bivalves were mostly found intact. Crustaceans were difficult to identify because they were almost always highly digested and fragmented. In most cases, only parts of the exoskeleton remained. Corycaeid copepods were rarely found whole and usually only the exoskeleton of the cephalosome remained. Barnacle larvae (cyprids) were often found intact, but in most cases only the exoskeleton was observed. Insects were also very fragmented, although more easily identifiable due to their dark exoskeleton. Our findings suggest that $A$. nigrescens is unable to the digest the exoskeletons of planktonic crustaceans and insects.

At both sites, the most common prey were juvenile bivalves, cypris larvae, and corycaeid copepods. Juvenile bivalves and cyprids were found in almost all examined coelenterons, whereas corycaeid copepods were found in about half. There were also differences in the percentage of each type of prey between sites. At Mata de Limón,

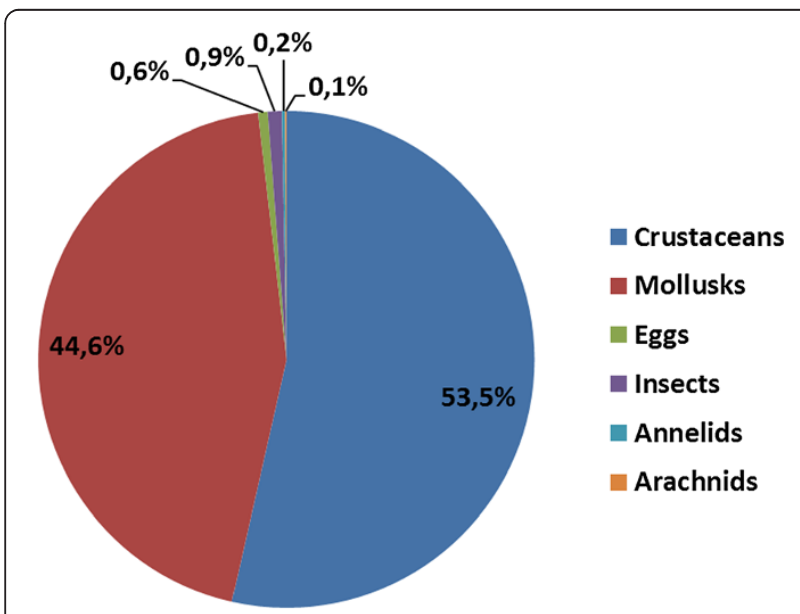

Figure 1 Composition of Anthopleura nigrescens diet at Playa Dominical, Puntarenas.

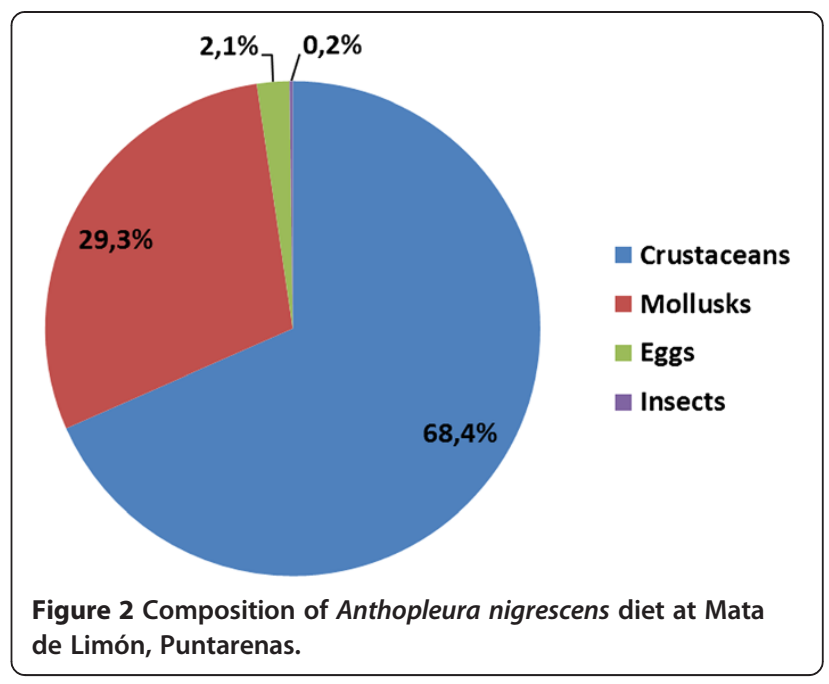

cyprids were the primary prey item (58\%), while juvenile bivalves were secondary prey (26\%) and copepods were occasional prey $(8 \%)$ (Table 1 ). In the population at Dominical, cyprids (47\%) and juvenile bivalves (44\%) were primary prey, while copepods were again occasional prey items (7\%) (Table 1). When data for both populations were combined, it is clear that $A$. nigrescens diet is composed mainly by cyprids and juvenile bivalves, complemented by occasional prey items such as copepods, gastropods, insects, and eggs.

The sea anemones at Playa Dominical captured considerably more juvenile bivalves during the nighttime high tide than during the daytime high tide, and captured slightly more cyprids during the night (Figure 3). The composition of prey items between tides was significantly different at this site (ANOSIM: $\mathrm{r}=0.06 ; \mathrm{p}<0.01$ ). Bivalves contributed substantially to the dissimilarity in the diet between tides (52.28\%), while cyprids contributed 26.25\%. The sea anemones at Mata de Limón captured more cyprids during daytime high tides than during nighttime high tides, and captured slightly more bivalves during the night that during the day (Figure 4). However, no significant differences were found in the composition of prey between tides (ANOSIM: $r=0.01 ; p=0.2$ ). The prey items that contributed most to the dissimilarity in the diet between daytime high tides and nighttime high tides were cyprids (42.51\%) and bivalves (41.11\%).

\section{Discussion}

A. nigrescens in our study preyed mainly on cypris larvae, juvenile bivalves and copepods. The predominance of cyprids may be explained by reproductive cycles in the local barnacle population and patterns in the larval settlement. Working in Punta Mala, on Costa Rica's Pacific coast, Sutherland (1990) found that the reproductive activity of Chthamalus fissus was high during the dry season (December-April), and that there was 
Table 1 Prey items in Anthopleura nigrescens collected

\begin{tabular}{|c|c|c|c|c|c|c|}
\hline \multirow[b]{2}{*}{ Prey } & \multicolumn{3}{|c|}{ Playa Dominical } & \multicolumn{3}{|c|}{ Mata de Limón } \\
\hline & $\mathbf{n}$ & $f$ & $\mathrm{P}(\%)$ & $\mathbf{n}$ & $f$ & $\mathrm{P}(\%)$ \\
\hline \multicolumn{7}{|l|}{ Mollusca } \\
\hline Juvenile bivalves & 626 & 0.91 & 43.6 & 242 & 0.90 & 25.7 \\
\hline Brachidontes puntarenensis & 1 & 0.01 & 0.1 & 20 & 0.24 & 2.1 \\
\hline Brachidontes semilaevis & - & - & - & 9 & 0.10 & 1.0 \\
\hline Gastropoda (unidentified) & 13 & 0.13 & 0.9 & 5 & 0.06 & 0.5 \\
\hline \multicolumn{7}{|l|}{ Crustacea } \\
\hline Cypris larvae & 667 & 0.99 & 46.5 & 550 & 0.94 & 58.3 \\
\hline \multicolumn{7}{|l|}{ Copepoda } \\
\hline Corycaeus & 93 & 0.43 & 6.5 & 74 & 0.59 & 7.8 \\
\hline Cyclopoida & - & - & - & 1 & 0.01 & 0.1 \\
\hline Harpacticoida & 2 & 0.02 & 0.1 & 1 & 0.01 & 0.1 \\
\hline Euterpina acutifrons & 1 & 0.01 & 0.1 & 4 & 0.06 & 0.4 \\
\hline Microsetella rosea & 1 & 0.01 & 0.1 & - & - & - \\
\hline Cirripedia & 1 & 0.01 & 0.1 & 8 & 0.11 & 0.8 \\
\hline Zoea larvae & - & - & - & 7 & 0.09 & 0.7 \\
\hline Decapoda: Majoidea & 1 & 0.01 & 0.1 & - & - & - \\
\hline Isopoda & 1 & 0.01 & 0.1 & - & - & - \\
\hline Cladocera, Evadne & 1 & 0.01 & 0.1 & - & - & - \\
\hline \multicolumn{7}{|l|}{ Arthropoda: Insecta } \\
\hline Insecta (unidentified) & 8 & 0.09 & 0.6 & - & - & - \\
\hline Hymenoptera & 3 & 0.03 & 0.2 & - & - & - \\
\hline Coleoptera & 2 & 0.02 & 0.1 & - & - & - \\
\hline Collembola, Anurida & - & - & - & 2 & 0.03 & 0.2 \\
\hline \multicolumn{7}{|l|}{ Arthropoda: Arachnida } \\
\hline Halacaridae & 2 & 0.02 & 0.1 & - & - & - \\
\hline \multicolumn{7}{|l|}{ Annelida } \\
\hline Polychaeta (unidentified) & 1 & 0.01 & 0.1 & - & - & - \\
\hline Sabellaridae & 1 & 0.01 & 0.1 & - & - & - \\
\hline Syllinae & 1 & 0.01 & 0.1 & - & - & - \\
\hline \multicolumn{7}{|l|}{ Other } \\
\hline Egg masses & 6 & 0.07 & 0.4 & 2 & 0.01 & 0.2 \\
\hline Eggs & 3 & 0.03 & 0.2 & 18 & 0.09 & 1.9 \\
\hline
\end{tabular}

Total number of each prey item $(n)$, prey item frequency index ( $f$ ), and prey item percentage (P), in Anthopleura nigrescens collected at Playa Dominical and Mata de Limón, Puntarenas.

a recruitment peak in the middle of the year. It is possible that the abundance of cyprids in our samples reveals a recruitment peak or simply reflects a large abundance of these larvae in the water column. Cyprids may be captured while swimming in the water column during their pelagic phase. Planktonic larvae may be carried towards the shore by a number of hydrodynamic processes (see Pineda et al. 2010) and currents in the intertidal zone can force the larvae into the tentacles of a sea anemone. Cyprids may also be captured if they wander onto the tentacles of a sea anemone during their settlement stage, when they walk on the substrate searching for a suitable place to cement themselves (Lagersson and Høeg 2002).

Bivalves were also an important component of $A$. nigrescens diet. Juvenile bivalves, which were too small to be identified, were presumably captured during the settlement process. Brachidontes are found attached to the rocky intertidal zone and may be caught by the sea anemones if they become detached from the substrate. Mytilid bivalves form aggregations and are subject to intraspecific competition that generates high levels of mortality in the population (Guiñez 2005). Moreover, bivalves in the intertidal zone are subjected to strong waves that can detach them from the substrate, depending on the size of the bivalve and how firmly it is adhered (Hunt and Scheibling 2001).

\section{Site to site differences in diet}

This study found few differences in A. nigrescens diet between sites. More mytilid bivalves were captured by the anemones in Mata de Limón than those in Playa Dominical and polychaetes were only found in sea anemones collected from Playa Dominical. These findings reflect the differences in the communities of potential prey items that colonize each site. The artificial breakwater in Mata de Limón receives low-energy waves that allow sessile organisms such as mytilid bivalves and barnacles to thrive, whereas the site at Playa Dominical receives high-energy waves and is only colonized by sea anemones and sabellid polychaetes. High wave energy results in slower bivalve growth rates and higher bivalve mortality (McQuaid and Lindsay 2000), and may hinder bivalve colonization of rocky sites in Playa Dominical.

The presence of insects in the specimens collected at Playa Dominical is noteworthy and reinforces the opportunistic feeding of these sea anemones. Several other studies have found insects in the coelenterons of sea anemones. For example, Acuña and Zamponi (1999) found coleopterans in Oulactis muscosa and Möller (1978) found six kinds of insects in Anemonia sulcata. Davenport et al. (2011) suggest that the presence of insects is determined by the direction of the wind, the location of the anemones on the coast, and the presence of abundant coastal vegetation. Our findings support this hypothesis, because Playa Dominical has abundant vegetation close to the intertidal zone, whereas the artificial breakwater at Mata de Limón lacks vegetation.

\section{Day to night differences in diet}

The main differences in diet between daytime and nighttime high tides are attributable to cyprids and juvenile bivalves, which comprise the bulk of $A$. nigrescens diet. Cyprids seem to be captured mostly during daytime high tides. Cruz (1999) found that settlement of Chthamalus 


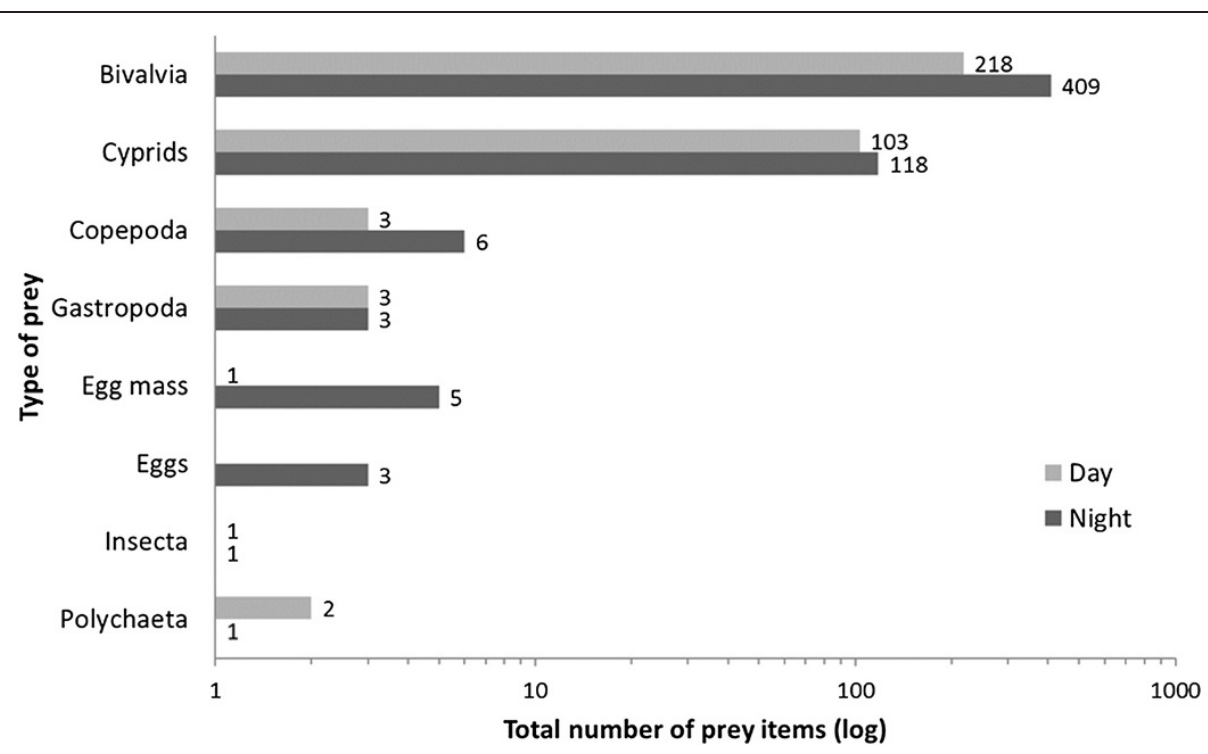

Figure 3 Daytime and nighttime prey items in Anthopleura nigrescens at Playa Dominical, Puntarenas. Total number of each prey item in Anthopleura nigrescens captured during daytime high tides and nighttime high tides at Playa Dominical, Puntarenas. Only partially digested and undigested prey items are included.

spp. in the low intertidal zone during daytime high tides was significantly higher than during the night, with densities of up to 74 cyprids and metamorphs per $25 \mathrm{~cm}^{2}$ quadrat. In another study, settlement of C. montagui was ten times higher during the day than during the night, which led the authors to hypothesize that cyprids use light as a cue to settle (Cruz et al. 2005). Conversely, in our study juvenile bivalves were captured predominantly during nighttime high tides. However, due to the difficulty of identifying the bivalves, it is not possible to know about their natural history, although data from this study suggest that they settle mainly at night.

We were unable to observe any patterns in copepod time of capture because they were rarely found undigested. However, it is likely that corycaeid copepods, which were an abundant prey item, are captured mainly during nighttime high tides. Many copepod species are part of the demersal plankton, organisms with vision

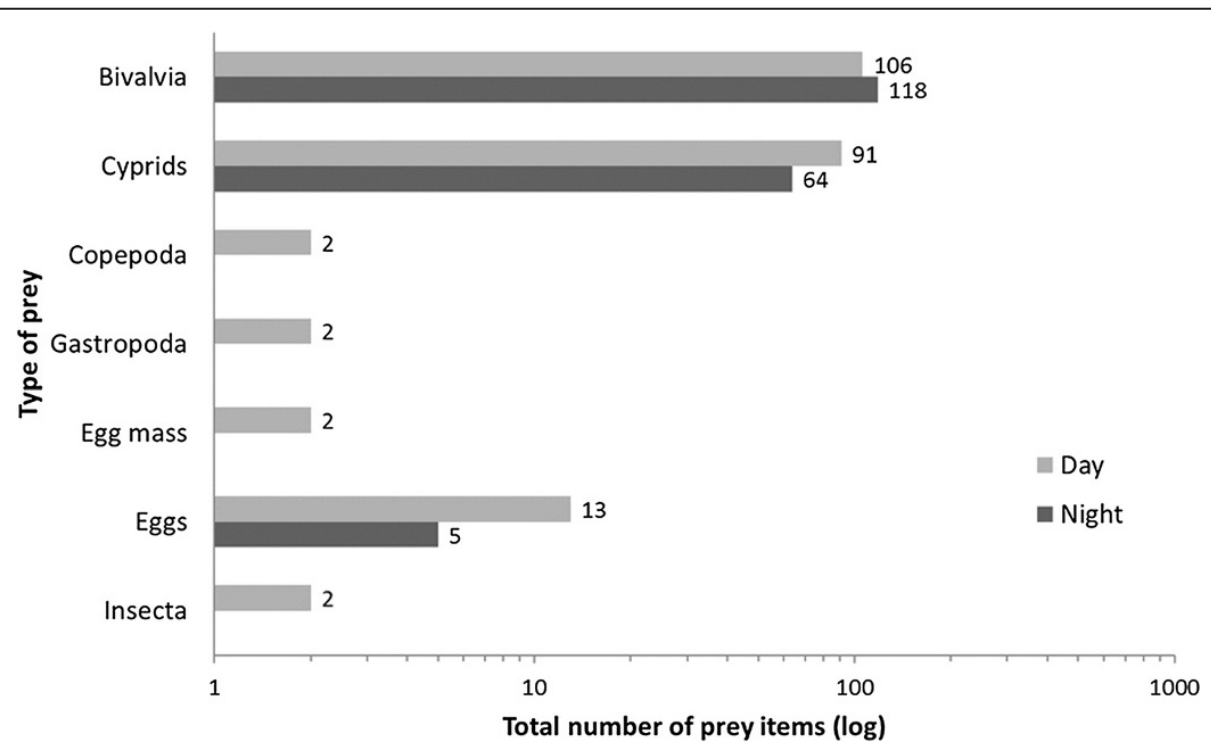

Figure 4 Daytime and nighttime prey items in Anthopleura nigrescens at Mata de Limón, Puntarenas. Total number of each prey item in Anthopleura nigrescens captured during daytime high tides and nighttime high tides at Mata de Limón, Puntarenas. Only partially digested and undigested prey items are included. 
and motility that hide in the benthos during the day and migrate into the water column at night (Alldredge and King 1977). Studies on zooplankton in coral reefs and subtidal sand flats have found that the abundance of corycaeid copepods increases during the night (Alldredge and King 1980; Ohlhorst 1982; Alldredge and King 1985; Nakajima et al. 2008). Heidelberg et al. (2004) propose that pelagic species that have a daily vertical migration offshore conserve such behavior in shallow environments. Also, demersal plankton such as copepods may migrate higher into the water column during full moon (Alldredge and King 1985), which may promote dispersal towards the shore.

We acknowledge that due to the lack of temporal replication in the present study it is difficult draw strong conclusions about the diurnal and nocturnal abundance patterns of the prey items in A. nigrescens diet.

\section{Conclusions}

The intertidal sea anemone $A$. nigrescens feeds mainly on juvenile bivalves and zooplankton such as cyprids and copepods. Insects are an occasional prey item that reflect the opportunistic character of this species. Moreover, the time of the high tides seems to have an effect on the types of prey that become available to the sea anemones. Our research shows that the diet may change not only between sites and depths, as other studies have revealed, but may also vary according to the time of day. We suggest that future trophic ecology studies should mention the time of day that specimens are collected, as results may be affected by temporal differences in prey availability. Finally, our findings show that $A$. nigrescens is an opportunistic polyphagous predators, like most of its temperate counterparts.

\section{Competing interests}

Authors declare they have no competing interests.

\section{Authors' contributions}

AJQ, FHA, and JC designed the study. AJQ collected, analyzed and interpreted the data, and drafted the manuscript. FHA and JC made intellectual contributions to the final draft of the manuscript and revised it critically. All authors read and approved the final manuscript.

\section{Acknowledgements}

We are grateful for the support provided by the Centro de Investigación en Ciencias del Mar y Limnología (CIMAR) of the Universidad de Costa Rica. Marco Corrales, Victoria Bogantes, Allan Carrillo, Steven Zamora, Jeffrey Sibaja, Kimberly García and Rita Vargas contributed to the identification of many prey items. We are very grateful for the financial support provided by the Quesada-Satterthwaite family. We would also like to thank Brian Bingham and two anonymous reviewers for their valuable comments that greatly improved this manuscript.

\section{Author details}

${ }^{1}$ Centro de Investigación en Ciencias del Mar y Limnología (CIMAR), Ciudad de la Investigación, Universidad de Costa Rica, San Pedro, San José 11501-2060, Costa Rica. ${ }^{2}$ Instituto de Investigaciones Marinas y Costeras, CONICET, Facultad de Ciencias Exactas y Naturales, Universidad Nacional de Mar del Plata, Funes 3250, Mar del Plata 7600, Argentina.
Received: 27 January 2014 Accepted: 19 May 2014

Published online: 17 June 2014

\section{References}

Acuña FH, Zamponi MO (1995) Feeding ecology of intertidal sea anemones (Cnidaria, Actiniaria): food sources and trophic parameters. Biociencias 3:73-84

Acuña FH, Zamponi MO (1996) Ecología trófica de las anémonas intermareales Phymactis clematis Dana, 1849; Aulactinia marplatensis (Zamponi, 1977) and A. reynaudi (Milne-Edwards, 1857) (Actiniaria: Actiniidae): relaciones entre las anémonas y sus presas. Ciencias Mar 22:397-413

Acuña FH, Zamponi MO (1999) Estructura poblacional y ecología trófica de Oulactis muscosa Dana, 1849 (Actiniaria, Actiniidae) del litoral Bonaerense (Argentina). Physis A57:11-16

Acuña FH, Excoffon AC, Genzano G (2001) Feeding of Anthothoe chilensis (Actiniaria, Sagartiidae) in Mar del Plata Port (Buenos Aires, Argentina). Biociencias 9:111-120

Acuña FH, Alvarado J, Garese A, Cortés J (2012) First record of the sea anemone Anthopleura nigrescens (Cnidaria: Actiniaria: Actiniidae) on the Pacific coast of Central America. Mar Biodivers Rec 5:e24. doi:10.1017/S175526721200022X

Alldredge AL, King JM (1977) Distribution, abundance, and substrate preferences of demersal reef zooplankton at Lizard Island Lagoon, great barrier reef. Mar Biol 41:317-333. doi:10.1007/BF00389098

Alldredge AL, King JM (1980) Effects of moonlight on the vertical migration patterns of demersal zooplankton. J Exp Mar Bio Ecol 44:133-156. doi:10.1016/0022-0981(80)90150-1

Alldredge AL, King JM (1985) The distance demersal zooplankton migrate above the benthos: implications for predation. Mar Biol 84:253-260. doi:10.1007/ BF00392494

Bingham BL, Freytes I, Emery M, Dimond J, Muller-Parker G (2011) Aerial exposure and body temperature of the intertidal sea anemone Anthopleura elegantissima. Invertebr Biol 130:291-301. doi:10.1111/j.1744-7410.2011.00241.x

Chintiroglou C, Koukouras A (1991) Observations on the feeding habits of Calliactis parasitica (Couch, 1842), Anthozoa, Cnidaria. Oceanol Acta 14:389-396

Chintiroglou C, Koukouras A (1992) The feeding habits of three Mediterranean sea anemone species, Anemonia viridis (Forskål), Actinia equina (Linnaeus) and Cereus pedunculatus (Pennant). Helgoländer Meeresuntersuchungen 46:53-68. doi:10.1007/BF02366212

Cruz T (1999) Settlement patterns of Chthamalus spp. at Praia da Oliveirinha (SW Portugal). Acta Oecol 20:285-287. doi:10.1016/S1146-609X(99)00138-1

Cruz T, Castro JJ, Delany J, McGrath D, Meyers AA, O'Riordan RM, Power A-M, Rabaça J, Hawkins SJ (2005) Tidal rates of settlement of the intertidal barnacles Chthamalus stellatus and Chthamalus montagui in western Europe: the influence of the night/day cycle. J Exp Mar Bio Ecol 318:51-60. doi:10.1016/j.jembe.2004.12.005

Davenport J, Moloney T, Kelly J (2011) Common sea anemones Actinia equina are predominantly sessile intertidal scavengers. Mar Ecol Prog Ser 430:147-155. doi:10.3354/meps08861

Deniel C (1975) Régimes alimentaires d'Amoglossus thori Kyle et d'Amoglossus imperialis Rafinisque (Teleosteens, Bothidae) en baie de Douarmenez. Rev des Trav l'Institut des Pêches Marit 39:105-116

Dunn DF (1974) Redescription of Anthopleura nigrescens from Hawaii. Pacific Sci 28:377-382

Guiñez R (2005) A review on self-thinning in mussels. Rev Biol Mar Oceanogr 40:1-6

Hammer $\varnothing$, Harper DAT, Ryan PD (2001) PAST: paleontological statistics software package for education and data analysis. Palaeontol Electron 4:9

Hart CE, Crowe JH (1977) The effect of attached gravel on survival of intertidal anemones. Trans Am Microsc Soc 96:28-41

Heidelberg KB, Sebens KP, Purcell JE (2004) Composition and sources of near reef zooplankton on a Jamaican forereef along with implications for coral feeding. Coral Reefs 23:263-276. doi:10.1007/s00338-004-0375-0

Hiebert TC, Bingham BL (2012) The effects of symbiotic state on heterotrophic feeding in the temperate sea anemone Anthopleura elegantissima. Mar Biol 159:939-950. doi:10.1007/s00227-011-1871-8

Hunt H, Scheibling R (2001) Predicting wave dislodgment of mussels: variation in attachment strength with body size, habitat, and season. Mar Ecol Prog Ser 213:157-164. doi:10.3354/meps213157

Kruger LM, Griffiths CL (1997) Digestion rates of prey eaten by intertidal sea anemones from the south-western Cape, South Africa. South African J Zool $32: 101-105$ 
Kruger LM, Griffiths CL (1998) Sea anemones as secondary consumers on rocky shores in the south-western Cape, South Africa. J Nat Hist 32:629-644. doi:10.1080/00222939800770331

Lagersson NC, Høeg JT (2002) Settlement behavior and antennulary biomechanics in cypris larvae of Balanus amphitrite (Crustacea: thecostraca: cirripedia). Mar Biol 141:513-526. doi:10.1007/s00227-002-0854-1

McQuaid C, Lindsay T (2000) Effect of wave exposure on growth and mortality rates of the mussel Perna perna: bottom-up regulation of intertidal populations. Mar Ecol Prog Ser 206:147-154. doi:10.3354/meps206147

Möller H (1978) Investigations on the feeding ecology of Anemonia sulcata. Zool Anz 200:369-373

Moore SJ (1989) Narcotising sea anemones. J Mar Biol Assoc United Kingdom 69:803-811

Nakajima R, Yoshida T, Othman BHR, Toda T (2008) Diel variation in abundance, biomass and size composition of zooplankton community over a coral-reef in Redang Island, Malaysia. Plankt Benthos Res 3:216-226. doi:10.3800/ pbr.3.216

Ohlhorst SL (1982) Diel migration patterns of demersal reef zooplankton. J Exp Mar Bio Ecol 60:1-15. doi:10.1016/0022-0981(81)90176-3

Pineda J, Porri F, Starczak V, Blythe J (2010) Causes of decoupling between larval supply and settlement and consequences for understanding recruitment and population connectivity. J Exp Mar Bio Ecol 392:9-21. doi:10.1016/j. jembe.2010.04.008

Purcell JE (2009) Extension of methods for jellyfish and ctenophore trophic ecology to large-scale research. Hydrobiologia 616:23-50. doi:10.1007/ s10750-008-9585-8

Rossi S, Ribes M, Coma R, Gili JM (2004) Temporal variability in zooplankton prey capture rate of the passive suspension feeder Leptogorgia sarmentosa (Cnidaria: octocorallia), a case study. Mar Biol 144:89-99. doi:10.1007/ s00227-003-1168-7

Sutherland JP (1990) Recruitment regulates demographic variation in a tropical intertidal barnacle. Ecology 71:955-972. doi:10.2307/1937365

Tsurpalo A, Kostina E (2003) Feeding characteristics of three species of intertidal sea anemones of the South Kuril Islands. Russ J Mar Biol 29:31-40. doi:10.1023/A:1022823819872

Verrill A (1928) Hawaiian shallow water anthozoa. Bernice P Bish Museum Bull 49:1-30

doi:10.1186/s40555-014-0026-2

Cite this article as: Quesada et al:: Diet of the sea anemone Anthopleura nigrescens: composition and variation between daytime and nighttime high tides. Zoological Studies 2014 53:26.

\section{Submit your manuscript to a SpringerOpen ${ }^{\circ}$ journal and benefit from:}

- Convenient online submission

- Rigorous peer review

- Immediate publication on acceptance

- Open access: articles freely available online

- High visibility within the field

- Retaining the copyright to your article

Submit your next manuscript at $>$ springeropen.com 